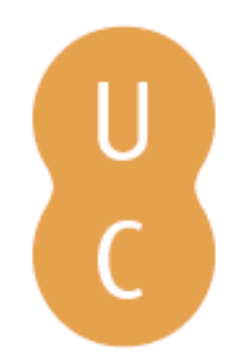

\title{
nommalina
}

\section{Forensic implications of a single duplication in DYS 448}

Autor(es): $\quad$ Vieira-Silva, C.; Lucas, I.; Espinheira, R.

Publicado por: Imprensa da Universidade de Coimbra; International Academy of Legal

URL

persistente: URI:http://hdl.handle.net/10316.2/31745

DOI: $\quad$ DOI:http://dx.doi.org/10.14195/978-989-26-0173-1_13

Accessed : $\quad$ 26-Apr-2023 16:19:22

A navegação consulta e descarregamento dos títulos inseridos nas Bibliotecas Digitais UC Digitalis, UC Pombalina e UC Impactum, pressupõem a aceitação plena e sem reservas dos Termos e Condições de Uso destas Bibliotecas Digitais, disponíveis em https://digitalis.uc.pt/pt-pt/termos.

Conforme exposto nos referidos Termos e Condições de Uso, o descarregamento de títulos de acesso restrito requer uma licença válida de autorização devendo o utilizador aceder ao(s) documento(s) a partir de um endereço de IP da instituição detentora da supramencionada licença.

Ao utilizador é apenas permitido o descarregamento para uso pessoal, pelo que o emprego do(s) título(s) descarregado(s) para outro fim, designadamente comercial, carece de autorização do respetivo autor ou editor da obra.

Na medida em que todas as obras da UC Digitalis se encontram protegidas pelo Código do Direito de Autor e Direitos Conexos e demais legislação aplicável, toda a cópia, parcial ou total, deste documento, nos casos em que é legalmente admitida, deverá conter ou fazer-se acompanhar por este aviso.

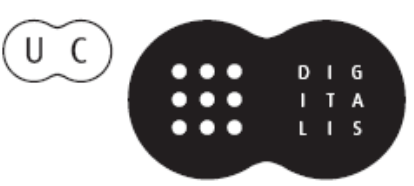




\section{Duarte Nuno Vieira Anthony Busuttil \\ Denis Cusack • Philip Beth}
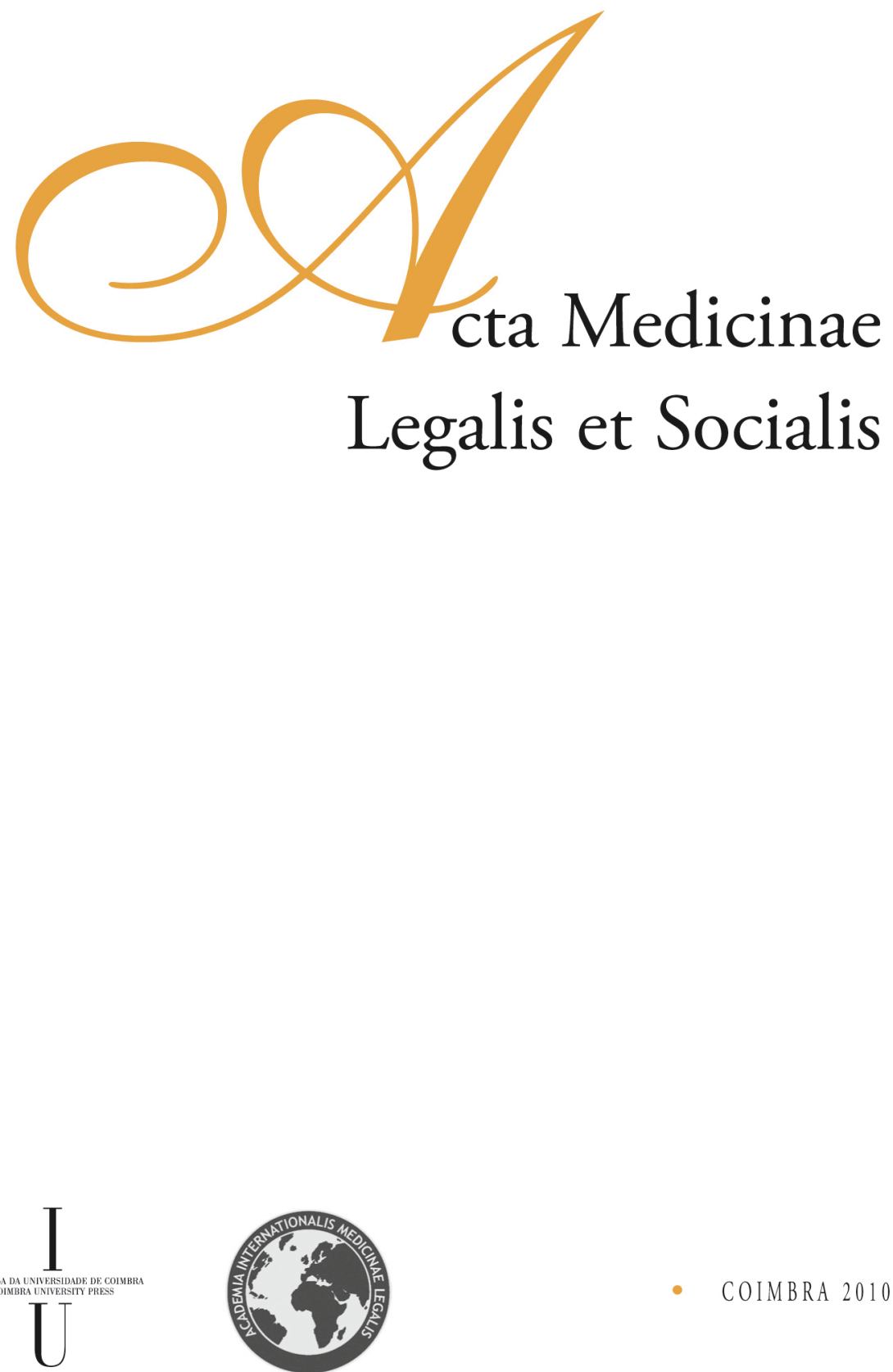
C. Vieira-Silva, I. Lucas, R. Espinheira

Forensic Genetics Service, South Branch of the National Institute of Legal Medicine, Lisbon, Portugal

FORENSIC IMPLICATIONS OF A SINGLE DUPLICATION IN DYS448

\begin{abstract}
The Y-Chromosome is specific to males and therefore very helpful in sexual assault cases. Commonly forensic used Y-STRs alleles are single-copy loci, however it is known that $\mathrm{Y}$-chromosome shows several structural variants such as copy duplications which can complicate evidentiary samples Y-STR profile analysis. With this work we focus on a DYS448 duplication obtained in a sexual assualt case evidence samples and the suspect reference sample matching.
\end{abstract}

Keywords: DYS448; duplication; AZFc region.

\title{
Introduction
}

The Y- Chromossome is specific to males and therefore very helpful in sexual assault cases where the perpretor's DNA needs to be identified in the presence of the male/female DNA mixtures.

Commonly used Y-STRs are single-copy loci, however it is known that in some Y-STR alleles, copy duplications could be observed in samples originated from a single individual. Large scale use of multiple Y-Chromosomal microsatellites in forensics can reveal such variants.

In this work we focus on a particular sexual assault case, whose victim's evidences - vaginal swab and a pair of undergarments- were in first step studied in search for male DNA contribution. These evidences reveal an allelic duplication at DYS448 lied on the proximal part of AZFc. In second step the suspect was also studied to compare with the evidences and the same duplication was detected on his profile. With this case study we pretend to show how a Y-chromosome duplication can reveal of whether or not a mixture of multiple allele DNA profile is present in an evidence sample.

\section{Methods}

Evidence's DNA was extracted with phenol/chloroform procedures and buccal swabs with Chelex method.

Purified DNA was quantified with Quantifiler ${ }^{\mathrm{TM}}$ Human DNA and Quantifiler ${ }^{\mathrm{TM}}$ Y Human Male DNA Quantification Kit (Applied Biosystems). All samples were 
extracted in duplicated and amplified with AMPFISTR ${ }^{\circ}$ Yfiler ${ }^{\circledR}$ PCR (Applied Biosystems) amplification kit according to manufacturer's.

PCR products electrophoresis was carried out on an ABI Prism 3130xl (Applied Biosystems). DNA fragments, allele typing and peak areas were analysed using the Genemapper 3.2 (Applied Biosystems).

\section{Results}

Figure 1 a) represents Y-STRs results obtained in victim's vaginal swab, which matched with her undergarments profile. Note that all loci were single copy alleles, even the highly polymorphic locus DYS385a/b have one single allele with area approximately twice that of the other Y-STR peaks in same dye color. The results revealed a duplication in DYS448 allelic range (Fig.1 b) with almost equal peak area and only one repeat unit apart. We concluded that this profile should come from only one donor. Later suspect buccal swab analysis revealed the same duplication, as can be seen in the Fig 2 a) and b). The suspect was the only one included from matching the evidentiary profile.

\section{Discussion}

In evidentiary samples from sexual assault cases, differentiation between male DNA mixtures and allele duplications must be evaluated according to published rules. In this case, was particular easy, because we had only two allele copies in DYS448 locus. The greater the number of loci, with more than one allele, besides DYS385a/b, greater the possibility of having two or more contributors in that sample, unless an entire region of Y-chromosome have been duplicated. Y-STRs information in sexual assault cases could be an important tool for detecting the number of male donors to an evidence specially in male/female mixtures.

Otherwise, locus duplication along the Y-chromosome can provide greater strength to a match between two samples, however should not prevent the reliable interpretation of mixtures.

Special attention should be given to these cases in order to prevent wrong inclusions or exclusions from a profile.

\section{Bibliography}

AMY E. DECKER et al, Analysis of mutations in father -son pairs with 17 Y-STR loci, For. Sci. Int.:Genetics 2, e31-e35, (2008).

JOHN M. BUTLER et al, Chromosomal duplications along the Y-chromosome and their Potential impact on Y-STR Interpretation, J. Forensic Sci, vol 50. No 4.853-859, July 2005

PATRICIA BALARESQUE, et al Dynamic nature of the proximal AZFc region of the human Y chromosome: multiple independent deletion and duplication events revealed by microsatellite analysis. Human Mutation, vol 29, issue 10 pages1171-1180, 2008. 
a)

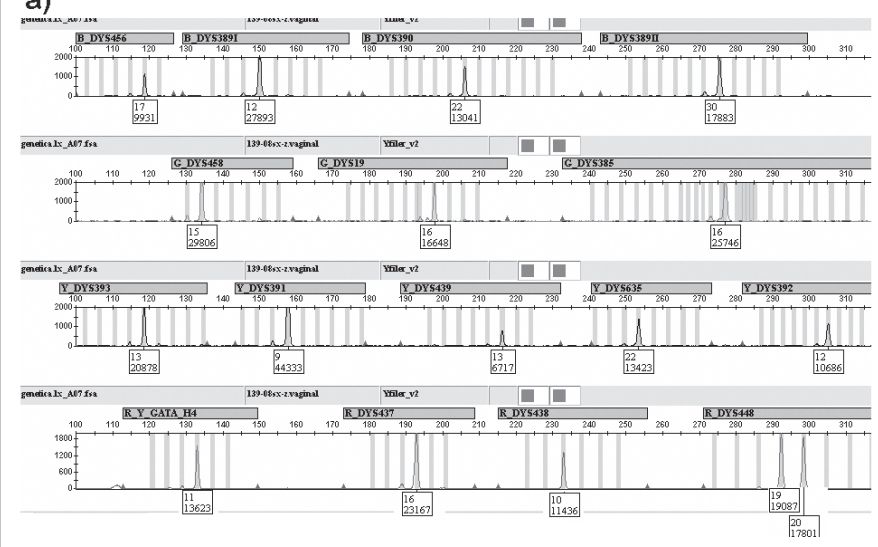

b)

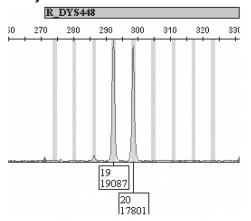

Figure 1 - vaginal swab Y-Filer profile a) and DYS448 loci allele duplication b)

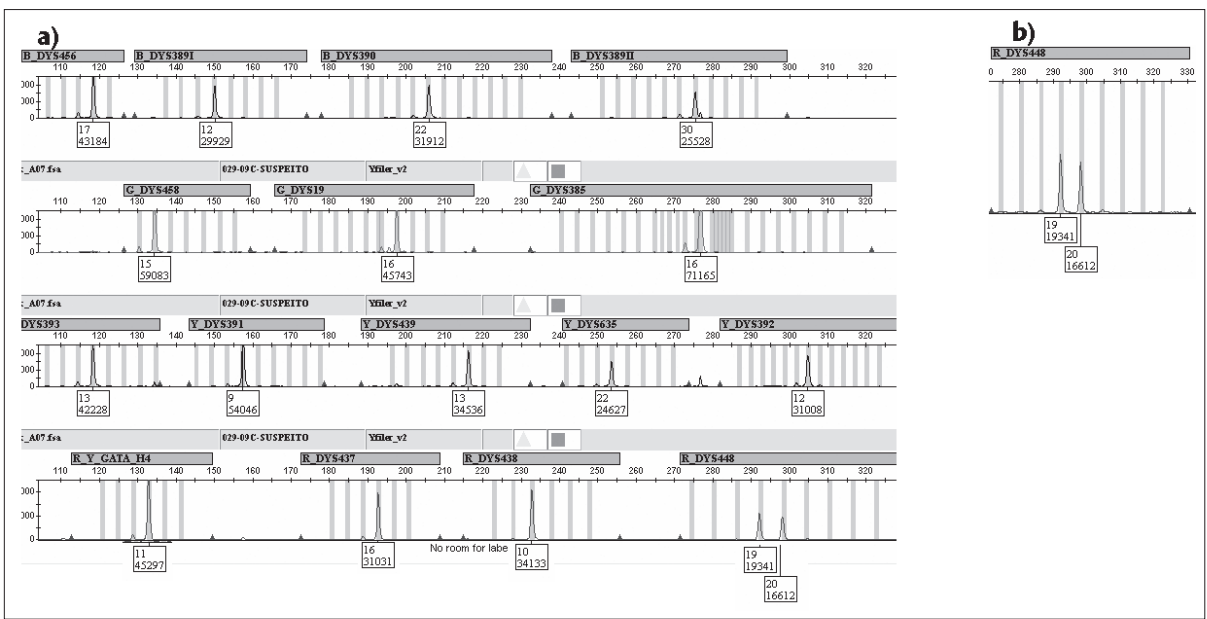

Figure 2 - Suspect Y-Filer profile a) and DYS448 loci allele duplication b) 